\title{
Efficacy of Time-Area Method in simulating temporal variation of sediment yield in Chehelgazi watershed, Iran
}

\author{
A.V. KHALEDI DARVISHAN, S.H.R. SADEGHI, L. GHOLAMI \\ Department of Watershed Management Engineering, College of Natural Resources and Marine \\ Sciences, Tarbiat Modares University, Iran
}

\begin{abstract}
Efficacy of Time-Area Method in simulating temporal variation of sediment yield in Chehelgazi watershed, Iran. The proper prediction of temporal and spatial variation of sediment yield from the watershed is a need for sediment control, river engineering and soil and water conservation studies. The present study was therefore planned to simulate the sediment graphs for Chehelgazi watershed in Gheshlagh dam upstream in Kurdistan Province, Iran, by using Time-Area Method. Towards this attempt, the study watershed was divided into 7 time-area segments based on the time of concentration. The soil erosion in each segment was estimated using the USLE and then routed to the main outlet using sediment delivery ratio as a function of land slope in two adjacent time-areas. The temporal variation of sediment was ultimately predicted with the help of lag time of sediment arrival to the outlet and the concept of superposition for 11 storm events, which occurred during winter 2006 and spring 2007. The comparison between estimated sediment graphs with corresponding observed ones verified the weak capability of the model in simulation of sediment graphs under consideration. The results also verified the calibration necessity of the model to achieve appropriate estimation for important components of the sediment graphs. The results of the calibration finally proved the considerable capability of the model in predicting of total volume of sediment yield with respective estimation and verification errors of 30.93 and $33.40 \%$.
\end{abstract}

Key words: Chehelgazi River, Iran, sediment delivery ratio, temporal variability of sediment, Time-Area Method (TAM).

\section{INTRODUCTION}

Suspended sediments in the river water flow depending on the flow energy and sediment concentration are deposited in different time and parts of the river. Information on the amount of sediment concentration in different periods in a river is important in planning projects and organizing river flood zoning. In many of the Iranian hydrometric stations, the sediment concentration are determined only in some severe storms without any evaluation of time distribution pattern of sediment. On the other hand, water and sediment sampling in given intervals and drawing hydrograph and sediment graph need a lot of time and costly laboratorial works. Therefore, developing models with ability of estimating temporal variations of sediment concentration for drawing sediment graph and measuring total amount of sediment is an inevitable need (Das and Agrawal 1990 and Sadeghi 2000).

The Time-Area Method (TAM) has the ability to estimate temporal variations in sediment. This method is based on the concept of temporal participation of different isochrones segments in supplying eroded materials to watershed 
output and naturally relevance the temporal variations in the amount of suspended sediment production to the sediments from erosion and arrival time to control point in every part (Kothyari et al. 1994 and Kothyari et al. 1997). Thus, the mentioned process requires having the appropriate method to estimate erosion in each isochrones segment, routing occurred erosion, estimating a sediment delivery ratio to the next segment and evaluate temporal participation of any part in total sediment production. In the first proposed version of TAM (Kothyari et al. 1994), the Universal Soil Loss Equation (USLE) model, the ratio between the slopes of the receiver and adjacent giving segments (Hadley et al. 1985) and the flow time in each isochrones segments have been used for simulating the sediment graph of watershed. In other words, the total catchment area can be divided into a number of subareas (referred here as time-area segments) by isochrones lines. The surface erosion within any time-area segment can be computed using the USLE method and finally, the eroded sediment can be routed to the catchment outlet through each time-area segment (Kothyari et al. 1994).

The application of TAM to estimate sediment graph despite simplicity, has been reported limitedly. Accordingly, Kothyari et al. (1994) have reported successful capability of the mentioned method in simulating storm-wise sediment graphs in some small watersheds in India. Some other researchers have reported the improving capability of the TAM through the intervention of forest land area in each isochrones segments and the application of geographi- cal information system to improvement sediment delivery ratio (Kothyari et al. 1997). Sadeghi and Tofighi (2003) have reported poor capability of TAM in simulating storm-wise sediment graphs in Khanmirza watershed in Iran. Because of different capability of TAM, the present study has been conducted to determine the efficiency of TAM in estimating storm-wise sediment graphs in Chehelgazi watershed in Gheshlagh dam upstream in Kurdistan Province, Iran.

\section{MATERIALS AND METHODS}

The Chehelgazi watershed of Gheshlagh Dam is located $46^{\circ} 45^{\prime}$ to $46^{\circ} 57^{\prime} \mathrm{E}$ longitude and $35^{\circ} 25^{\prime}$ to $35^{\circ} 38^{\prime} \mathrm{N}$ latitude as shown in Figure 1. The entire watershed falls in the Kurdestan provice with mean slope of $17.57 \%$, minimum, maximum and average elevation respectively of 1550, 2840 and 2200 meters above mean sea level and average annual precipitation of $294.2 \mathrm{~mm}$. This watershed coverage range and agricultural lands with respectively areas of 23465 and 3768 ha.

In order to assess the applicability of TAM in simulating temporal variations of sediment in storm-wise basis, the suspended sediment samples were taken from the outlet of Chehelgazi watershed (Fig. 1) for 11 storm events during October 2006 to April 2007 by using one litter bottle samplers and depth integration technique (Das and Agrawal 1990). The concentration of suspended sediment for all samples were then measured by using filtration method (American Society of Civil Engineers 2006) and finally, sediment graphs were drawn on storm basis. The study watershed was then divided based on isochrone segments obtained 

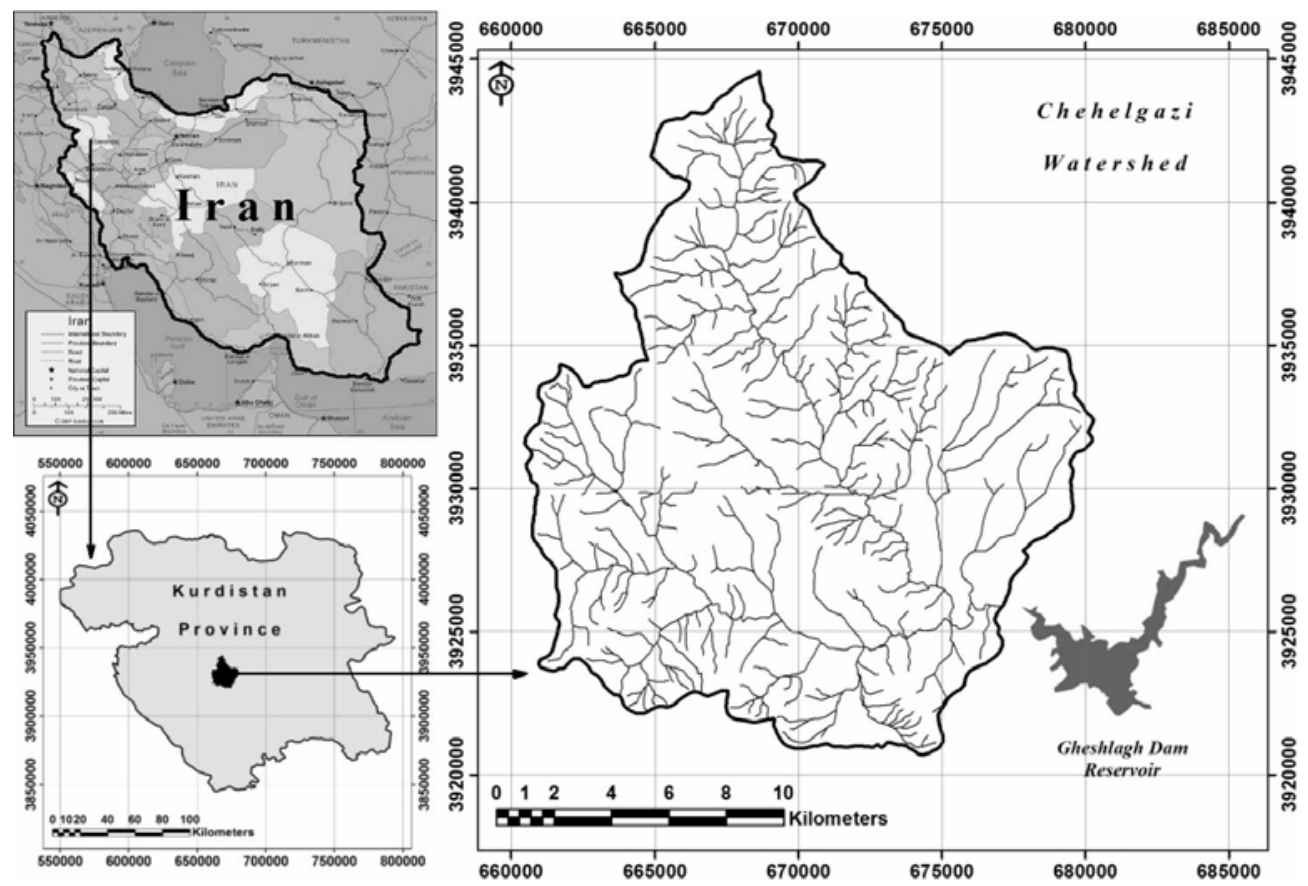

FIGURE 1. Location of Chehelgazi watershed in Iran

through criterion given by Subramanya (1999) and represented in (1).

$$
n=(3 \text { to } 5)\left(T_{c} / T_{l}\right)
$$

where:

$T_{c}$ is time of concentration (h) and $T_{l}$ is lag time (h).

Isochrones were situated based on equal divisions of main river longitudinal profile. The associated elevations of selected points were determined and corresponding contour lines were drawn on topography map (Subramanya 1999). The erosion rate in each individual segment was estimated by using USLE model (Wischmeier and Smith 1978) and routed to the next segment by considering sediment delivery ratio $(S D R)$ determined as a function of land slope in two adjacent time-area segments (Kothyari et al. 1994 and Kothyari et al. 1997) to obtain sediment yield resulted from each particular segment. The entire sediment yield resulted from a storm was ultimately calculated through combining routed sediment to the main outlet each segment as represented in (2) (Kothyari et al. 1994 and Kothyari et al. 1997).

$$
\begin{aligned}
V_{s}= & S D R_{1} E_{1}+S D R_{1} S D R_{2} E_{2}+\ldots \\
& +S D R_{1} S D R_{2} \ldots S D R_{n} E_{n}
\end{aligned}
$$

where:

$S D R_{i}$ is sediment delivery ratio for each pair adjacent segments, $E_{i}$ is erosion in each isochrone segment ( $\mathrm{t}$ ) and $V_{s}$ is amount of sediment yield in watershed $(\mathrm{t})$. 


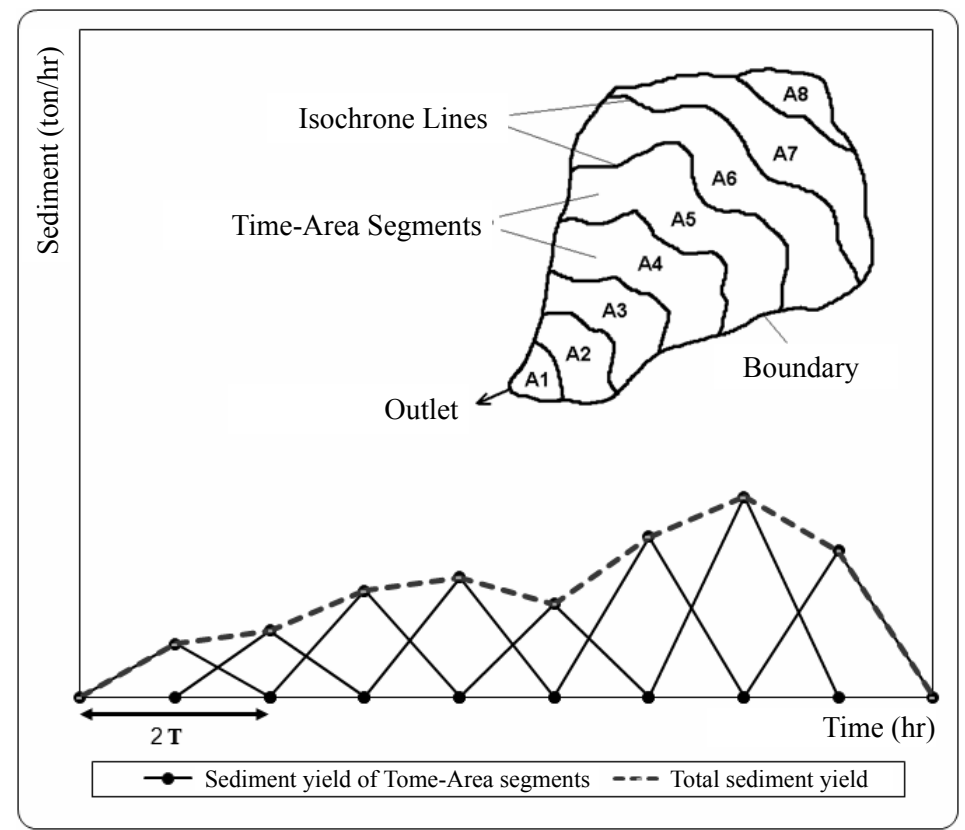

FIGURE 2. The conceptual graph of TAM

Temporal distribution of sediment for each segment was then estimated with the help of total sediment yield and time required for sediment from each segment to reach the main output of the watershed (Kothyari et al. 1994). The superposition approach was finally applied to simulate the total sediment graph of the watershed resulted from a particular storm event. The details of the procedure has been shown in Figure 2. The estimated and observed sediment graphs were consequently compared qualitatively and quantitatively in view points of general shapes and total volume of sediment yield.

\section{RESULTS AND DISCUSSION}

As methodology explained above, the isochrone map of Chehelgazi watershed was developed for applying e TAM. The results of detailed information and developing isochrone map have been shown in Table 1 and Figure 3, respectively.

The results of application of the USLE and corresponding estimated sediment yield from 11 storm events occurred during study period (October 2006 to April 2007) as well as associated comparisons in total sediment yield have been summarized in Table 2 .

The TAM concept used for the present study and resulted in simulating sediment graphs also led to Figures given in Figure 4. The results in Table 2 and estimated sediment graph presented in Figure 4 showed that the total sediment yield estimated by TAM in all 11 study storms were more than observed ones. In other words, the difference between the total sediment yields was very significant 
TABLE 1. Detailed information for isochrone map of Chehelgazi watershed

\begin{tabular}{|c|c|c|r|c|c|}
\hline Segments & Time of concentration $(\mathrm{h})$ & Elevation $(\mathrm{m})$ & \multicolumn{1}{c|}{ Area $(\mathrm{h})$} & Slope $(\%)$ & Sediment delivery ratio \\
\hline A1 & 0.4 & 1570 & 93.924 & 15.15 & 0.77 \\
\hline A2 & 0.8 & 1640 & 588.304 & 19.72 & 0.98 \\
\hline A3 & 1.2 & 1715 & 1505.636 & 20.08 & 1.00 \\
\hline A4 & 1.6 & 1790 & 2060.647 & 17.59 & 1.00 \\
\hline A5 & 2.0 & 1865 & 2813.209 & 17.38 & 0.96 \\
\hline A6 & 2.4 & 1995 & 6646.840 & 18.11 & 1.00 \\
\hline A7 & $\approx 2.8$ & 2400 & 13509.066 & 17.35 & 0.90 \\
\hline
\end{tabular}

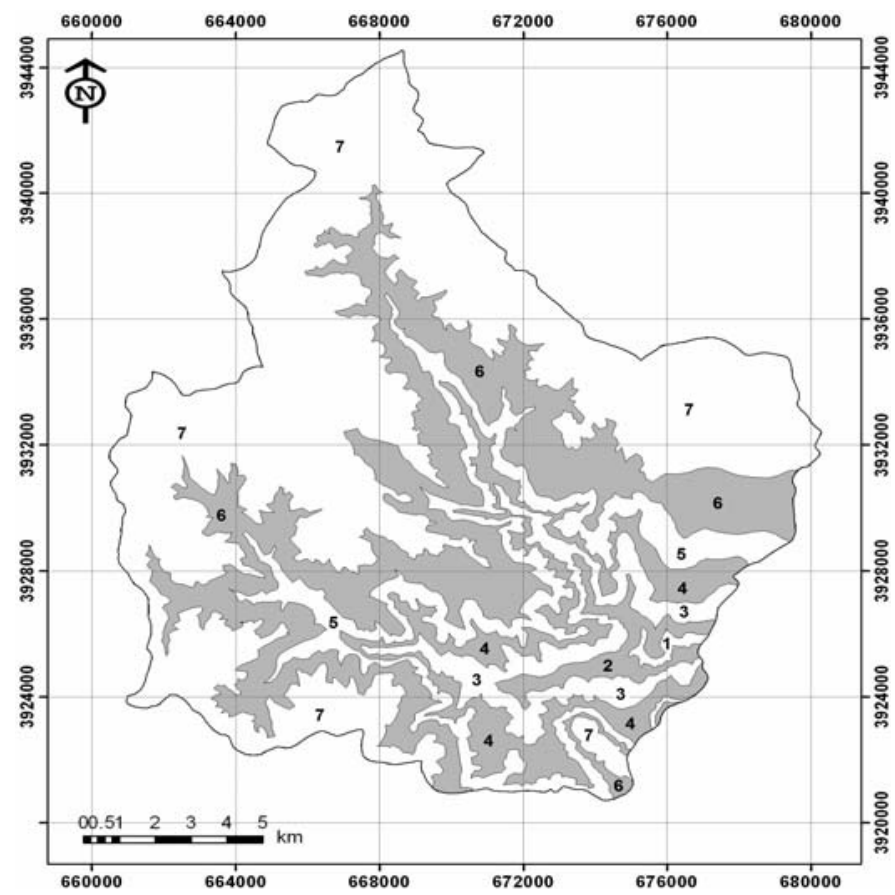

FIGURE 3. The isochrone map of Chehelgazi watershed in Gheshlagh dam upstream

TABLE 2. Comparison between observed and estimated total sediment yield from TAM

\begin{tabular}{|c|c|c|c|}
\hline Date & Estimated sediment $(\mathrm{t})$ & Observed sediment $(\mathrm{t})$ & Error of the estimate (\%) \\
\hline 26.10 .2006 & 98.74 & 64.81 & 52.35 \\
\hline 31.10 .2006 & 4472.74 & 140.00 & 3094.81 \\
\hline 05.11 .2006 & 340.35 & 27.81 & 1124.99 \\
\hline 20.11 .2006 & 88.86 & 35.02 & 153.77 \\
\hline 27.11 .2006 & 770.14 & 53.14 & 1349.32 \\
\hline 10.12 .2006 & 6072.26 & 59.20 & 10157.19 \\
\hline 06.02 .2007 & 444.31 & 43.00 & 933.28 \\
\hline 24.02 .2007 & 4082.73 & 105.40 & 3773.56 \\
\hline 26.03 .2007 & 3149.68 & 58.90 & 5247.50 \\
\hline 09.04 .2007 & 1352.68 & 107.90 & 1153.64 \\
\hline 26.04 .2007 & 13428.09 & 180.00 & 7360.05 \\
\hline
\end{tabular}



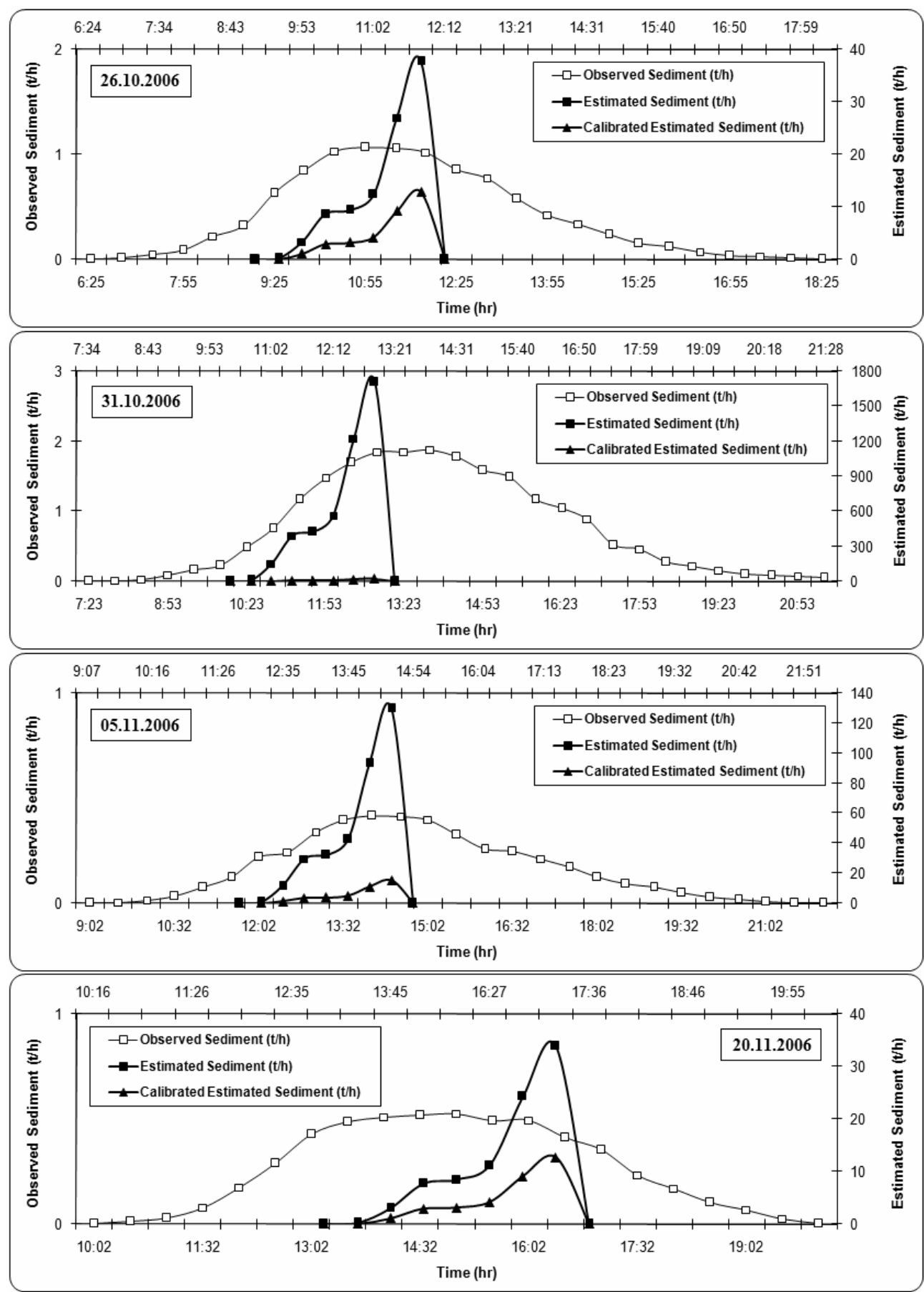

FIGURE 4. Observed and estimated sediment graphs of study storms 

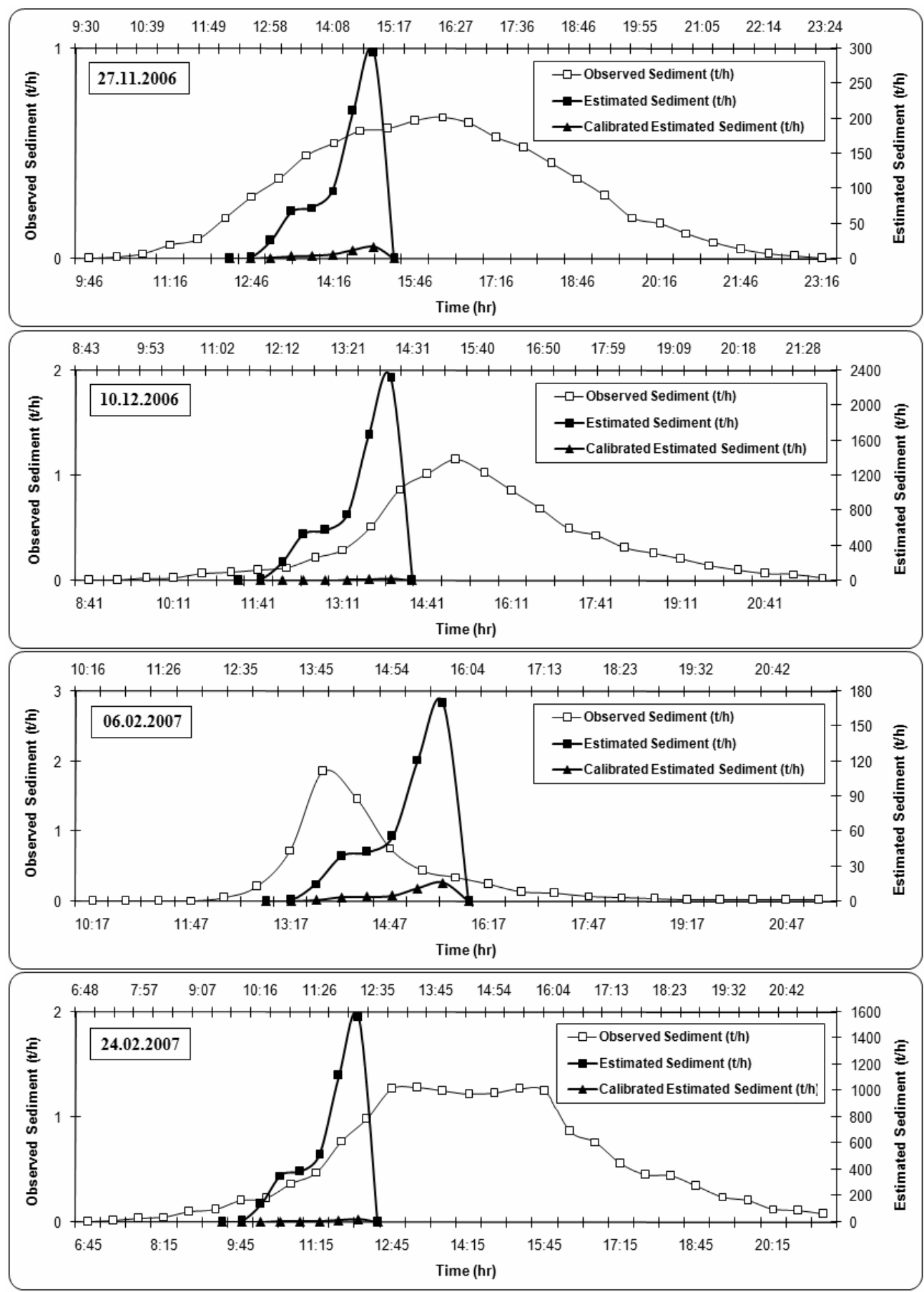

FIGURE 4 (continued) 


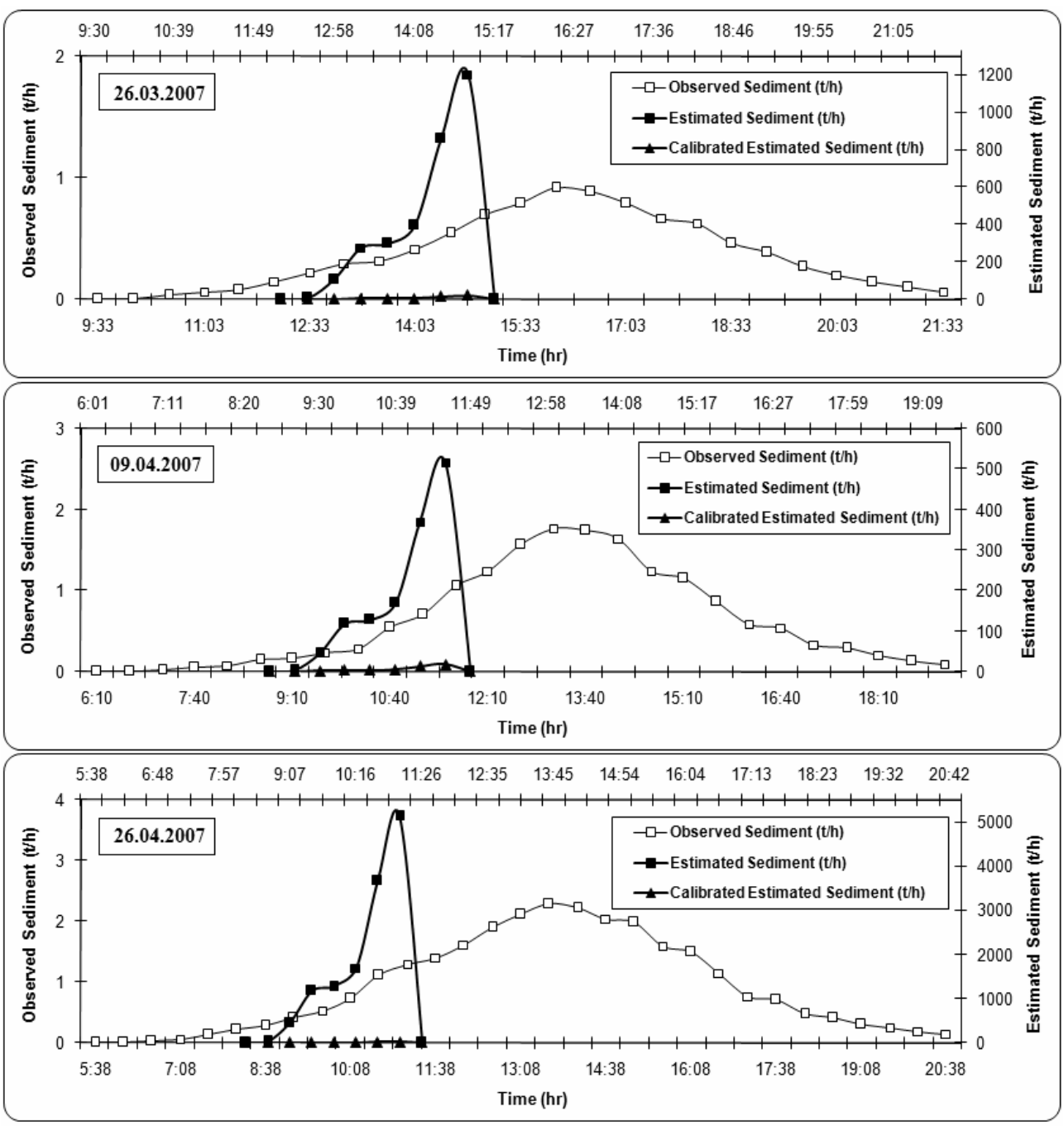

FIGURE 4 (continued)

so that the estimated values were found to be some hundred more than observed sediment yield in some storms. This was obvious generally in storms with higher sediment. The results therefore showed poor capability of the TAM to estimate storm-wise sediment yield and simulate sediment graphs in the study watershed. This disagreed with Kothyari et al.
(1994) who showed good capability of the TAM to estimate sediment graphs in some small watersheds in India.

To improve the applicability of the TAM in the study watershed, further attempt was made for the calibration. The results of the model calibration has been shown in (3) and corresponding results of application of revised model 
for calibration and verification stages have been respectively summarized in Tables 3 and 4.

$$
\begin{aligned}
V_{s}= & 17.7 \times\left(S D R_{1} E_{1}+S D R_{1} S D R_{2} E_{2}+\right. \\
& \left.\ldots+S D R_{1} S D R_{2} \ldots S D R_{n} E_{n}\right)^{0.14}
\end{aligned}
$$

Considering Tables 3 and 4 verified that the calibrated TAM had relatively better capability than the non-calibrated version in estimation of storm-wise total sediment yield in study watershed so that, the estimation error for calibration and verification stages were found 30.93 and 33.40 , respectively.

Therefore, it can be said that the calibrated TAM has only high capability in estimate storm-wise total sediment yield while its performance in estimation of temporal variations which in turn is necessary for developing sediment graphs is very poor. It can be understood from the results that the entire hypothesis based on which the TAM has been developed are not logically applicable for the study watershed. The large area, non-uniform rainfall distribution and different surface conditions can then be supposed as some affecting factors controlling weak performance of the TAM in the study watershed. These findings are verified by results obtained in watersheds with smaller area (Kothyari et al. 1997 and Sadeghi and Tofighi 2003).

\section{CONCLUSION}

The present study has been conducted to assess the capability of the TAM in simulating temporal variation of sediment yield which in turn will be necessary for drawing sediment graphs for Chehelgazi watershed in Gheshlagh dam upstream in Kurdistan Province, Iran. It can be concluded from the results that the calibrated TAM could provide good estimates for storm-wise total sediment yield, while it could not simulate temporal variations

TABLE 3. Comparison between observed and estimated total sediment yield from calibrated TAM for calibration stage for Chehelgazi watershed

\begin{tabular}{|c|c|c|c|}
\hline Date & Estimated sediment $(\mathrm{t})$ & Observed sediment $(\mathrm{t})$ & Error of the estimate (\%) \\
\hline 26.10 .2006 & 33.67 & 64.810 & 48.05 \\
\hline 31.10 .2006 & 57.42 & 140.000 & 58.99 \\
\hline 20.11 .2006 & 33.17 & 35.020 & 5.27 \\
\hline 27.11 .2006 & 44.88 & 53.140 & 15.54 \\
\hline 06.02 .2007 & 41.56 & 43.000 & 3.35 \\
\hline 24.02 .2007 & 56.69 & 105.400 & 46.21 \\
\hline 26.03 .2007 & 54.67 & 58.900 & 7.19 \\
\hline 26.04 .2007 & 66.97 & 180.000 & 62.79 \\
\hline
\end{tabular}

TABLE 4. Comparison between observed and estimated total sediment yield from Calibrated TAM for validation stage for Chehelgazi watershed

\begin{tabular}{|c|c|c|c|}
\hline Date & Estimated sediment $(\mathrm{t})$ & Observed sediment $(\mathrm{t})$ & Error of the estimate (\%) \\
\hline 05.11 .2006 & 40.04 & 27.810 & 43.98 \\
\hline 10.12 .2006 & 59.93 & 59.200 & -1.23 \\
\hline 2007 & 48.57 & 107.900 & 54.99 \\
\hline
\end{tabular}


of sediment. However, drawing final conclusion needs more extensive studies and analyses in the study area and other watersheds with different geo-climatic conditions.

\section{REFERENCES}

American Society of Civil Engineers (2006): Sedimentation Engineering: Theory, Measurements, Modeling and Practice 1801. Alexander Bell Drive, Reston, VA, USA, 424 p.

DAS G., AGRAWAL A., 1990: Development of Conceptual Sedimentgraph Model. Am J Agr. E., 33(1), 100-104.

HADLEY R.F., LAI R., ONSTAD C.A., 1985: Recent Development in Erosion and Sediment Yield Studies. UNESCO Publications, Paris, France, $127 \mathrm{pp}$.

KOTHYARI U.C., JAIN S.K., 1997: Sediment Yield Estimation using GIS. Hydrolog Sci J., 42(6), 833-843.

KOTHYARI U.C., TIWARI A.K., SINGH R., 1994: Prediction of Sediment Yield. J Irrig Drain E-ASCE, 12 (6), 11-20.

KOTHYARI U.C., TIWARI A.K., SINGH R., 1997: Estimation of temporal variation of sediment yield from small catchments through the kinematic method, J. Hydrol., 203, 39-57.

SADEGHI S.H.R., 2000: Some Aspects of Spatial and Temporal Distribution and Development of Prediction Model of Watershed Sediment Yield. PhD Dissertation, G.B.P. University of Agriculture and Technology, India, $362 \mathrm{pp}$.

SADEGHI S.H.R., TOFIGHI B., 2003: Capability of Time-Area Method in developing sediment graph (case study: Khanmirza River in
Karoun Basin), Research Journal of Agriculture \& Natural Resources Science (Khazar), 1, 54-66 (in Persian).

Subramanya K., 1999: Engineering hydrology, Tata McGraw-Hill, India, 391 pp. 13.

WISCHMEIER W.H., SMITH D.D., 1978: Predicting Rainfall Erosion Losses - A Guide to Conservation Planning. Agriculture Handbook, No 537, Washington DC.

Streszczenie: Efektywność metody TAM (Time-Area Method) w symulacji zmienności czasowej wydatku rumowiska ze zlewni Chehelgazi, Iran. W artykule przedstawiono zastosowanie metody TAM do symulacji zmienności czasowej wydatku rumowiska ze zlewni Chehelgazi, położonej w prowincji Kurdystan w Iranie. Zlewnię Chehelgazi podzielono na 7 zlewni cząstkowych, biorąc za podstawę czas koncentracji odpływu rumowiska. Do wyznaczenia masy rumowiska transportowanego w czasie wezbrania opadowego wykorzystano uniwersalne równanie strat glebowych USLE. Na podstawie sedymentogramów 11 zarejestrowanych wezbrań opadowych przeprowadzono weryfikację i kalibrację metody TAM. Błąd estymacji i weryfikacji całkowitej objętości wydatku rumowiska ze zlewni wyniósł odpowiednio 30.9 i $33.4 \%$.

\section{MS. received April 2010}

\section{Authors' address:}

Department of Watershed Management Engineering College of Natural Resources and Marine Sciences Tarbiat Modares University Noor 46417-76489, Mazandaran, Iran e-mail: vahedkhaledi@yahoo.com 